\title{
A proposal for measuring hotels' managerial responses to User-Generated-Content Reviews
}

\author{
Una propuesta de medida de la gestión de los hoteles de las valoraciones generadas por el usuario
}

\author{
Javier Perez-Aranda \\ University of Malaga, Faculty of Economics and Business, Department of Business Management, Campus de Teatinos, 29071 \\ Málaga, Spain, jpereza@uma.es \\ María Vallespín \\ University of Malaga, Faculty of Economics and Business, Department of Business Management, Campus de Teatinos, 29071
} Málaga, Spain, mvallespin@uma.es

\section{Sebastian Molinillo}

University of Malaga, Faculty of Economics and Business, Department of Business Management, Campus El Ejido, 29013 Málaga, Spain, smolinillo@uma.es

\begin{abstract}
Despite the fact that User-Generated-Content (UGC) has emerged as a widely implemented practice in many disciplines and industries, including tourism and hospitality, academic research lacks a measurement method for hotels' managerial responses to UGCReviews (UGC-R). Based on data from a survey of 335 hotels, this article validates a 32 -item UGC-Review scale that, through a battery of exploratory factorial analysis tests, comprises 6 constructs: identification of the reputation landscape; assessment of changes in the company's ratings and rankings over time; determination of the publication reach; comparison with industry competitors; review and comparison of ranking methodologies and increased reputational scores. The results show that the proposal scale demonstrates reliability and dimensionality. The proposed UGC-R scale is a strategic tool for business managers aiming to improve their marketing strategies and to gain insights into the competitive advantage of reputation management.
\end{abstract}

Keywords: eWOM, User-generated-content, review sites, ranking, hotel.

\section{Resumen}

Aunque el Contenido Generado por el Usuario (UGC) ha emergido como una práctica ampliamente implementada en muchas disciplinas e industrias, incluyendo el turismo, la investigación académica carece de un método de medición de la gestión de los hoteleros de las valoraciones generadas por el usuario (UGC-R). Basándonos en datos de una encuesta de 335 hoteles, este artículo valida una escala de gestión del contenido generado por el usuario (UGC-Review) de 32 ítems que, a través de una batería de pruebas basadas en el análisis factorial exploratorio, comprende 6 constructos: identificación del panorama de reputación; evaluación de los cambios en las calificaciones y clasificaciones de la empresa a lo largo del tiempo; determinación del alcance de la publicación; comparación con los competidores de la industria; revisión y comparación de las metodologías de clasificación y aumento de la reputación. Los resultados muestran que la escala propuesta presenta confiabilidad y dimensionalidad. La escala UGC-R propuesta es una herramienta util para gerentes de negocio que pretendan mejorar sus estrategias de marketing y obtener información sobre la gestión de la reputación como ventaja competitiva.

Palabras clave: Boca a boca electrónico, contenido generado por el usuario, plataforma de valoración, ranking, hotel.

\section{Introduction}

According to Weilin \& Svetlana (2015), User-Generated-Content (UGC) is defined as creative content published on accessible websites and created without a direct link to monetary profit or other interests (e.g., commercial). Since their initial beginnings, UGC websites have evolved into a variety of formats, such as virtual communities (e.g., Lonely Planet), consumer reviews (e.g., TripAdvisor), personal stand-alone blogs (Tumblr), social networks (e.g., Facebook), media sharing tools (e.g., Flickr, YouTube), and wikis (e.g., Wikitravel) (Xiang \& Gretzel, 2010). The amount of digital data accumulated from countries and industries doubles every 1.2 years (Weilin \& Svetlana, 2015).

The development of UGC is a result of the explosion of the Internet and mobile technologies, allowing customers to review products and services, document travel experiences, and upload photos and videos or other information such us complaints. UGC is widely used by consumers in the tourism sector, in particular, to share information and as an information source to help them make decisions (Gretzel \& Yoo, 2008). Due to the intensity and speed of growth of UGC in the tourism sector, reputation management has been given priority in organizations' day-to-day operations (Baka, 2016).

UGC-based articles in the tourism literature are, firstly, largely concerned with issues of customer satisfaction, complaint behavior, and service failure and recovery. A large amount of studies examine customer reviews from TripAdvisor and other similar websites as their source of UGC. Most of these studies have been conducted within the context of accommodations, rather than other areas such as airline companies, travel agencies or restaurants. Secondly, UGC research in the field of tourism is mostly concerned with applications that explore the various aspects of service quality, destination image and reputation, experiences and behavior, the persuasive power of UGC such as eWOM, as well as tourist mobility patterns. Textual UGC and content analysis are, respectively, the leading types of data and research methods used. The overall trend, however, is to expand the repertoire of analytical and computational procedures, with an increasing number of studies using specialized software to manage the big data dimension of UGC (Weilin \& Svetlana, 2015). 
Although many studies target UGC, none have focused on measuring the managerial response to UGC-R, especially within the context of hotel accommodations. Thus, our objective here is to develop a multidimensional UGC-Review scale. In particular, this article contributes to the literature by providing an analysis of the UGC-R process within the context of tourist accommodations, by proposing a scale to effectively measure the degree of UGC-R response from tourist accommodations organizations. The study population is Spanish tourist accommodations that are posted on TripAdvisor.

The proposed scale could serve as an important tool for managers and hoteliers wishing to measure their organizations' UGC-R strategy and the impact of their review strategies on performance. In order to shed light on this topic, this paper contributes to UGC research in the hotel industry by proposing a scale for measuring the hotels' response strategies in regard to UGC-Reviews. This exploratory study allows for an initial practical application of the literature's theoretical criteria.

The article's structure, as recommended by Santos and Custodio (2015), is as follows: the first section establishes a theoretical framework, reviewing prior research on the concept of UGC-R, and proposes the conceptualization of an UGC-Review response scale consisting of 6 different dimensions; the second section analyzes the proposed UGC-R response scale; and finally, the paper concludes with a discussion of the intended contributions, implications for theory and management, limitations, and suggestions for future lines of research.

\section{Literature review}

\subsection{User-Generated-Content}

UGC has been defined as an electronic communication phenomenon enabled by Web 2.0, varying from travel blogs and social networking sites to travel wikis and forums (Baka \& Scott, 2009). These tools allow people to collaborate and share information online (Cox, Burgess, Sellitto, \& Buultjens, 2009) based on any form of media ranging from video, wikis, blogs, recommendations, social networking, forums, and message boards. Therefore, due to the experiential nature of tourism products, and the fact that the prior quality of said products cannot be determined a posteriori, potential tourists highly rely on UGC to form an image of the product (Gretzel, Yoo, \& Purifoy, 2007; Pan, MacLaurin, \& Crotts, 2007; Cox et al., 2009). Consequently, UGC serves as an information source for potential tourists (Ye, Gu, Chen, \& Law, 2008). Due to the high credibility of UGC, it can help tourists and travelers form an image of a tourist destination.

Since the emergence of this phenomenon, there has been an exponential increase in UGC literature and, in particular, studies that examine online reviews. In recent years, UGC reviews have been extensively studied in regard to service quality (Li, Ye, \& Law, 2012; Magnini, Crotts, \& Zehrer, 2011), experiences and behavior (Axup \& Viller 2005; Berger \& Greenspan, 2008; Pan et al., 2007; Marine-Roig \& Anton, 2015; Marchiori \& Cantoni, 2015;
Paris \& Rubin 2013), destination image and reputation (Choi, Lehto, \& Morrison, 2007; Dwivedi, Yadav, \& Patel, 2009; Law \& Cheung, 2010; Schmallegger \& Carson, 2009; Wenger, 2008), influence on travel decisions (Arsal, Wosnam, Baldwin, \& Backman, 2010; Baka, 2016; Cheng \& Loi, 2014; Magnini et al., 2011; Duffy, 2015; Filieri \& McLeay, 2013; Hvass \& Munar, 2012; Herrero, Martin, \& Hernandez, 2015; Jin \& Phua, 2016; Leung, Schuckert, \& Yeung, 2013; Liu, 2012; Jani, Jeong, \& Hwang, 2011; Kwok \& Yu, 2013; Lu \& Stepchenkova, 2012; O’Connor, 2011; Sparks, Perkins, \& Buckley, 2013; Xiang \& Gretzel, 2010) and mobility patterns (Ardizzone, Di Miceli, La Cascia, \& Mazzola, 2012; Girardin, Dal Fiore, Blat, \& Ratti, 2007; Girardin, Calabrese, Fiore, Ratti, \& Blat, 2008; Kurashima, Tezuka, \& Tanaka, 2005; Lu, Wang, Yang, Pang, \& Zhang, 2010). In terms of the methodology used in these studies, the most frequently used analytical procedure in most areas is content analysis and the dominant data type is text (Weilin \& Svetlana, 2015).

According to Hoffman and Fodor (2010), word-of-mouth (WOM) is created in a different manner in the most common social media applications. WOM in blogs is based on: the number of references to blogs in other media, the number of reblogs, and the number of badge items displayed on other sites. WOM in microblogs (i.e. twitter) is based on the number of retweets and likes. For product reviews (i.e. Amazon and TripAdvisor) is based on: the number of reviews posted, the review balance (ratio of positive to negative reviews), the number and balance of other users' responses to reviews, the number of references to reviews on other sites, the number of visits to a review site page, the number of times a product is included in users' lists. For social networks (i.e. Facebook, LinkedIn): the frequency of appearances in friends' timelines, the number of post on a Wall, the number of reposts/shares, and the number of responses to friend referral invitations. For video and photo sharing (i.e. Flickr and YouTube): the number of times it is embedded, the number of incoming links, the number of references in mock-ups or derived work, the number of items republished in other social media, and the number of "likes".

Regarding to review responses, some authors' studying reviews of hospitality organizations only focus on the different approaches to online review responses used by hotels. For instance, scholars have concluded that some hotels respond to every single review while others rarely or never respond online, while others respond to every review for a short period of time and then go silent again (Park \& Allen, 2013), providing incentives for both positive and negative eWOM (Kim, Naylor, Sivadas, \& Sugumaran, 2015). Along these lines, Park and Allen (2013) focus on how hotels, even within the same brand families, have different responses, including active follow-up, apology, appreciation, compensation, correction, explanation, passive follow-up, and requests for future patronage (Levy, Duan, \& Boo, 2013).

\subsection{User-Generated-Content in Tourism}

According to Lu and Stepchenkova (2015), the widespread use of social media combined with developments in software 
instruments is drawing the attention of researchers towards using UGC as a form of research in tourism and hospitality applications. In their review work in tourism science, Lu and Stepchenkova have concluded that UGC research is focused on service quality, destination image and reputation, experiences and behavior, the persuasive power of UGC as eWOM, and tourist mobility patterns.

The study entitled "Social Media Use in European Hotels" by Garrido-Moreno and Lockett (2016) shows a compilation of social media tools used in tourism and its significance. According to these authors, review sites such as TripAdvisor are the most widely used of all social media tools, therefore making it necessary to further study how managers can manage reviews. Moreover, the use of review sites such as TripAdvisor in the tourism sector is becoming crucial as they are known to have an influence on over US\$10 billion of online travel purchases made every year (Ye, Law, Gu, \& Chen, 2011). According to the organization's 2016 fact sheet, over 340 million visitors visit the site every month. TripAdvisor offers over 320 million traveler reviews of 1,000,000 hotels and 4,000,000 restaurants (TripAdvisor, 2016).

TripAdvisor, in particular, which is the most popular site for tourists to evaluate accommodations, has a clearly influence on the travel industry and popular culture (Jeacle \& Carter, 2011). The content generated on TripAdvisor's website has transformed reputation into a highly contested issue with critical implications. Reviews have provided the basis for travelers to make conclusions about the legitimacy and reputation of hotels (Baka, 2016). TripAdvisor is a website that offers travel advice to users, with the following purpose (Tripadvisor, 2016):

"TripAdvisor is the world's largest travel site, enabling travelers to plan and book the perfect trip. TripAdvisor offers advice from millions of travelers and a wide variety of travel choices and planning features with seamless links to booking tools that check hundreds of websites to find the best hotel prices. TripAdvisor branded sites make up the largest travel community in the world, reaching 350 million unique monthly visitors, and 320 million reviews and opinions covering more than 6.2 million accommodations, restaurants and attractions. The sites operate in 48 markets worldwide."

In addition to identifying the hotel identification and the user, a typical TripAdvisor review includes: an overall score (from 1 to 5 stars), a title (maximum 120 letters), and a review text (minimum 100 letters). In addition to this information, users can choose to specify what they liked and disliked about the hotel and provide sub-scores for various aspects of the hotel (i.e. rooms, cleanliness, service, etc.). Furthermore, users can provide personal information and details regarding the date and purpose of their visit (i.e. travel dates, age range, etc.). To finish the review, users can answer some questions about their recommendations (O'Mahony \& Smyth, 2010). From the perspective of hotel organizations, hotel managers are now including the task of checking the reviews about their hotel on TripAdvisor as part of their daily routine. Major hotel brands have established new strategies designed to respond to potential reputation crises triggered by TripAdvisor ranking and reviews (Baka, 2016). TripAdvisor has therefore been selected as the review site in this study in order to develop and propose a scale for UGC-R response strategy.

\subsection{User-Generated-Content Review (UGC-R) in tourism}

Baka (2016) proposes a conceptual model for managing online reputation management as a way of conceptualizing the transformation process in reputation development in the travel industry. She argues that reviews on websites, infomediaries and social networks with several rating mechanisms and specific areas for comments open up communication channels with customers, while also leading managers to develop reputation management strategies.

According to Baka, UGC introduces a different form of representation, which is arguably more akin to word-of-mouth. More importantly though, the emergence of social media and electronic WOM (eWOM) has influenced traditional practices ranging from the dissemination of information to feedback management. Nowadays, managers can use analytics to study where visitors come from and where they "go" after they interact with any initiative they introduce on their websites or social networks (such as offers and discounts). Being aware of the channels that bring more traffic and reservations, managers are better informed of where they should focus their efforts. Baka highlights some online practices in the era of social media, such as: online monitoring and tracking traffic; performance measurement using Google analytics, web analyzers and other sophisticated tools; the use of social media to advertise campaigns and offers; YouTube channels for uploading videos and featuring destinations; free widgets and screensavers that users can download and use (some of which allow direct booking); exclusive benefits for a channel's fans and followers (discounts offered only to Twitter or Facebook fans); Facebook like and share buttons and groups on Facebook, Linkedln, Twitter, etc.; correlating information on various platforms to identify who the customers are (for instance TripAdvisor reviews with reservation records); bonuses and promotions based on social media feedback; and user-generated "inspections".

Baka's methodology is based on a netnographic approach including 21 hoteliers, 5 hostel owners, 4 travel bloggers, 2 travel community founders, and 49 users, through online engagement to the TripAdvisor community. The empirical material used to demonstrate how UGC is challenging existing reputation management strategies was collected on TripAdvisor. Baka proposed a model based on specific steps for reputation tracking in the era of lists and rankings from Fombrun's work (2007). The 6 steps used by Baka adapted from Fombrun are: 1 . identify the reputation landscape; 2 . assess changes in the company's ratings and rankings over time; 3. determine publication reach and readership; 4 . compare with 
industry competitors; 5 . review and compare ranking methodologies; 6. improve reputational scores. The model seems to modulate in three main stages (as seen in Figure 1): firstly, through the identification and analysis of position methodology (including identifying the reputation landscape and assessing changes in the company's ratings and rankings over time); secondly, through management reviews and ratings (determining publication reach and readership; comparing with industry competitors); and thirdly, controlling and improving outcomes (reviewing and comparing ranking methodologies and improving reputational scores).

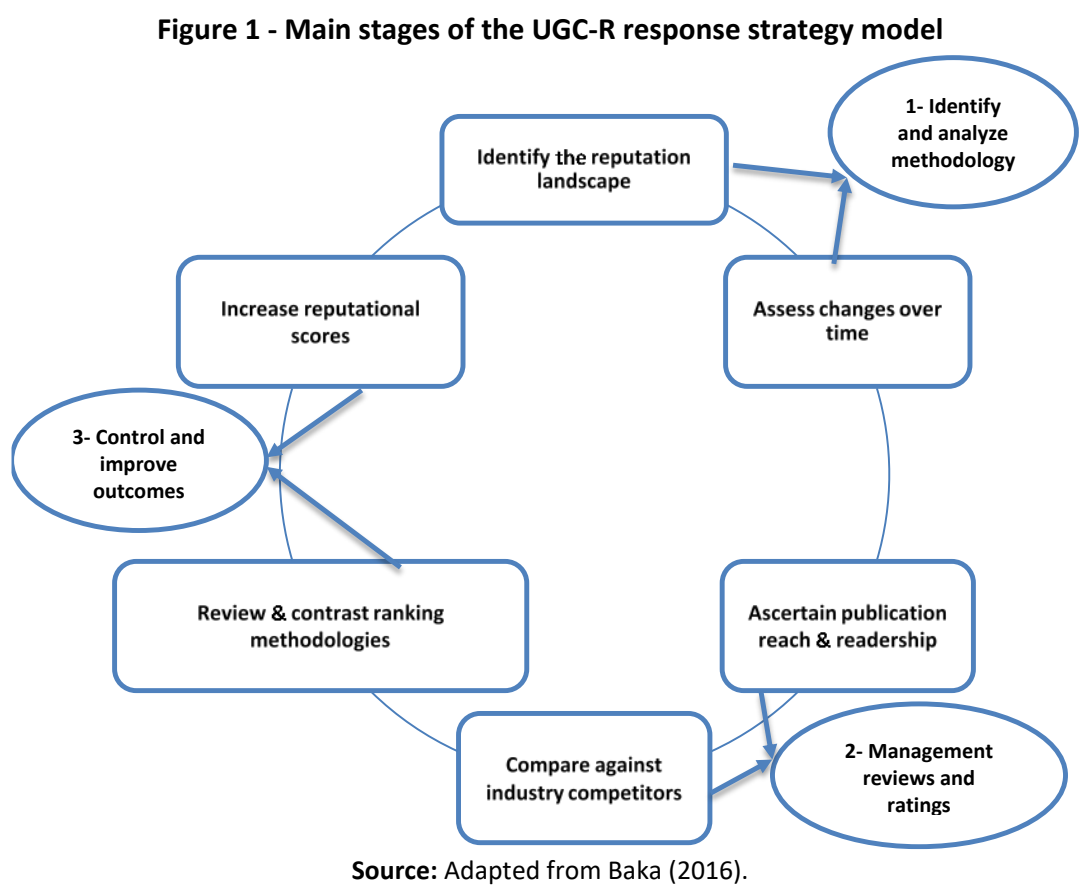

Therefore, based on the idea that UGC-R is a tool for boosting hotels' reputational impact, this study proposes measuring UGC-R response strategy according to Baka's dimensions. Since each dimension seems to work for a different target, the dimensions will be analyzed to see if they can be aggregated based on a common objective: identifying the reputation landscape and assessing changes in the company's ratings and rankings over time were aggregated in "methodology identification and analysis"; determining the publication reach and readership and comparing it with industry competitors were aggregated in "management reviews and ratings"; and reviewing and comparing ranking methodologies and improving reputational scores were aggregated in "improving outcomes".

\section{Methodology}

\subsection{Data collection}

This section focuses on explaining the steps taken to achieve our objective of analyzing the intensity of using UGC-R for Spanish hotels posted on TripAdvisor, categorizing the hotels into different groups and validating a measurement scale for UGC-R response strategy. Empirical research started with a qualitative phase focused on developing the scale. The designed scale was therefore presented to hotel managers, marketing professionals and academics. Interviews were conducted with 6 tourism experts, 5 marketing professionals and 4 academic experts. As a result of this process some questions were added, others were eliminated and the text and expression of some of them changed for the better understanding of the respondent.
To collect the information, it was followed the key-informant methodology, choosing the hotel managers as informants. Table 1 shows the technical specifications of fieldwork conducted. From a directory of 1978 Spanish hotels posted on TripAdvisor in March 2016, the information regarding this target population was collected using systematic random sampling, with the first element chosen at random from said population and other elements selected at regular intervals (i.e. systematizing item selection using a lift coefficient). In this case, the assumed margin of error was $5 \%$, so a sample of 332 participants was selected, so $1978 / 332=5.9$ (lift coefficient). The fieldwork data was collected in Spain. Five interviewers conducted a telephone survey in April and May of 2016. For details see table 1.

\section{Table 1 - Technical data and sample characteristics}

\begin{tabular}{|l|l|}
\hline \multicolumn{1}{|c|}{ Universe } & Spanish hotels in TripAdvisor \\
\hline Population & 1978 \\
\hline Sampling element & Key-informant \\
\hline Sample size & 332 \\
\hline Sampling type & Systematic random sampling \\
\hline Sampling fieldwork & April and May 2016 \\
\hline Sampling technic & Telephone interview \\
\hline Sample error* & $4.9 \%$ \\
\hline \begin{tabular}{l} 
Note. \\
level of $95 \%$ (according to the principles of simple random sampling) \\
\hline
\end{tabular} \\
\hline
\end{tabular}

\subsection{Variable dimensions}

The questionnaire is structured in two sections, with a total of 44 questions. The first section deals with classification variables 
including: the hotel category, size by number of beds, size by number of employees, ownership of the establishment, the use of review sites, ability to use review sites, and commitment to the review sites. The second section consists of 32 questions classified according to six dimensions, following the model proposed by Baka (2016). Table 2 shows the main features of the scale, each dimension and the sources. In this case, the variables are measured according to a 10-point Likert scale, from 1 (strongly disagree) to 10 (totally agree). The measurement instrument, obtained after discussing the pretest technique, is shown in Appendix 1.

Table 2 - Dimension items

\begin{tabular}{|c|c|c|}
\hline Dimension & $\begin{array}{c}\text { Item } \\
\text { number }\end{array}$ & Source \\
\hline $\begin{array}{l}\text { Identification of the } \\
\text { reputation landscape }\end{array}$ & 4 & $\begin{array}{c}\text { Baka (2016), Jeacle \& Carter (2011), } \\
\text { O'Mahony \& Smyth (2010). }\end{array}$ \\
\hline $\begin{array}{l}\text { Assessment of changes } \\
\text { in the company's ratings } \\
\text { and rankings over time }\end{array}$ & 4 & $\begin{array}{l}\text { Baka (2016), Nieto, Hernández- } \\
\text { Maestro, \& Muñoz-Gallego (2014). }\end{array}$ \\
\hline $\begin{array}{l}\text { Determination of } \\
\text { publication reach }\end{array}$ & 12 & $\begin{array}{l}\text { Baka (2016), Kim, et al., (2015), Levy et } \\
\text { al. (2013), Park, \& Allen, (2013) Sparks, } \\
\text { et al. (2016), Zhang \& Vasquez (2014). } \\
\text { Baka (2016), Kim et al. (2015), Levy et } \\
\text { al. (2013), Park et al., (2013). }\end{array}$ \\
\hline $\begin{array}{l}\text { Comparison with } \\
\text { industry competitors }\end{array}$ & 4 & Baka (2016), Min et al. (2002). \\
\hline $\begin{array}{l}\text { Reviewing ranking } \\
\text { methodologies }\end{array}$ & 4 & Baka (2016), O’Mahony et al. (2010). \\
\hline $\begin{array}{l}\text { Improving reputational } \\
\text { scores }\end{array}$ & 4 & $\begin{array}{l}\text { Baka (2016), Molinillo, Ximénez-de- } \\
\text { Sandoval, Fernández-Morales, \& Coca- } \\
\text { Stefaniak (2016). }\end{array}$ \\
\hline
\end{tabular}

\section{Results}

In order to evaluate the measurement scale for UGC-Review response strategy, the underlying structure and the latent constructs of the data have been analyzed. Principal Component Analysis (PCA) with Varimax rotation has been performed for each of the three main stages of reputation tracking.

The number of factors to be extracted was selected based on our own discretion. Two phases are expected for each stage. Regarding the results of the three PCA, the value of the KaiserMeyer-Olkin (KMO) index was greater than 0.8 and Bartlett's test of sphericity was always significant, demonstrating the correlation structure. Furthermore, the extracted communalities and factor loadings exceeded 0.7 in all cases. Lastly, reliability was assessed with Cronbach's alpha and values over 0.7 were obtained, as required in exploratory phases.

\subsection{Identifying and analyzing the applicable methodology}

In the first stage, two factors were extracted, explaining $97.082 \%$ of the total variance (see Table 3). The first factor consists of 4 items associated with the identification of the reputation landscape, which explains $48.73 \%$ of the variance. The second factor combines 4 items related to the assessment of changes in the company's ratings and rankings over time, which explains $48.35 \%$ of the variance.

Table 3 - Dimensionality and reliability analysis: identification and analysis of the methodology

\begin{tabular}{|c|c|c|c|}
\hline Factors & Variables & $\begin{array}{l}\text { Factor } \\
\text { Loadings }\end{array}$ & Communalities \\
\hline \multirow{4}{*}{$\begin{array}{l}\text { Identification of the reputation } \\
\text { landscape } \\
48.73 \% \\
\alpha=0.991\end{array}$} & $\begin{array}{l}\mathrm{X} 1 \text { : Knowing the specific areas where customers can } \\
\text { send or read general reviews }\end{array}$ & 0.851 & 0.978 \\
\hline & $\begin{array}{l}\text { X2: Knowing the specific areas where customers can } \\
\text { send or read specific reviews }\end{array}$ & 0.846 & 0.972 \\
\hline & $\begin{array}{l}\text { X3: Knowing the specific areas where customers can } \\
\text { rate general aspects of the hotel }\end{array}$ & 0.849 & 0.980 \\
\hline & $\begin{array}{l}\text { X: Knowing the specific areas where customers can } \\
\text { rate specific aspects of the hotel }\end{array}$ & 0.837 & 0.972 \\
\hline \multirow{4}{*}{$\begin{array}{l}\text { Assessment of changes in the } \\
\text { company's ratings and rankings } \\
\text { over time } \\
48.35 \% \\
\alpha=0.988\end{array}$} & X5: Evaluating changes in the number of comments & 0.831 & 0.962 \\
\hline & $\begin{array}{l}\text { X6: Evaluating changes in comments (from positive to } \\
\text { negative and from negative to positive) }\end{array}$ & 0.853 & 0.965 \\
\hline & $\mathrm{X7}$ : Evaluating changes in the number of ratings & 0.830 & 0.966 \\
\hline & $\begin{array}{l}\text { X8: Evaluating changes in ratings (from positive to } \\
\text { negative and from negative to positive) }\end{array}$ & 0.851 & 0.971 \\
\hline
\end{tabular}

Note. $\mathrm{KMO}=0.937$ Barlett's sphericity test $\mathrm{X}^{2}(28)=6080.232(\mathrm{p}=0.000)$ Residuals $=0 \%$ Source: Authors.

\section{2. Managing reviews and rating}

In the second phase, two factors are also shown that explain $83.853 \%$ of the variance. The first factor combines 12 items related to the response patterns to online reviews, explaining
$57.99 \%$ of the variance. The second factor consists of 4 items explaining $25.85 \%$ of the variance (see table 4 ). 
Table 4 - Dimensionality and reliability analysis: managing reviews and rating

\begin{tabular}{|c|c|c|c|}
\hline Factors & Variables & $\begin{array}{l}\text { Factor } \\
\text { loading }\end{array}$ & Communalities \\
\hline \multirow{12}{*}{$\begin{array}{l}\text { Response patterns to } \\
\text { online reviews } \\
57.99 \% \\
\alpha=0.983\end{array}$} & X9: Responding promptly to positive evaluations & 0.909 & 0.924 \\
\hline & X10: Expressing thanks for evaluations made & 0.901 & 0.910 \\
\hline & $\mathrm{X} 11$ : Giving innovative responses to comments & 0.899 & 0.895 \\
\hline & $\mathrm{X} 12$ : Highlighting positive aspects reflected in the evaluation & 0.903 & 0.919 \\
\hline & X13: Addressing specific comments & 0.857 & 0.865 \\
\hline & X14: Expressing thanks for evaluations made about the hotel & 0.878 & 0.881 \\
\hline & X15: Apologizing for any aspects that have caused low ratings & 0.825 & 0.844 \\
\hline & X16: Explaining the aspects that have caused low ratings & 0.799 & 0.835 \\
\hline & $\begin{array}{l}\text { X17: Offering the opportunity to contact the hotel in order to carefully address the } \\
\text { issue that has caused a poor evaluation }\end{array}$ & 0.799 & 0.790 \\
\hline & $\begin{array}{l}\text { X18: Sharing information about corrective actions carried out based on poor } \\
\text { evaluations }\end{array}$ & 0.845 & 0.812 \\
\hline & $\begin{array}{l}\text { X19: Providing some form of compensation (monetary or non-monetary) for } \\
\text { inconveniences the customer has experienced }\end{array}$ & 0.733 & 0.583 \\
\hline & X20: Inviting customers back to the hotel & 0.858 & 0.848 \\
\hline \multirow{4}{*}{$\begin{array}{l}\text { Comparison with } \\
\text { industry competitors } \\
25.85 \% \\
\alpha=0.923\end{array}$} & $\begin{array}{l}\text { X21: Management of the hotel's online comments involves identifying and } \\
\text { prioritizing customer service attributes that influence the customer's perception of } \\
\text { the quality of service }\end{array}$ & 0.910 & 0.872 \\
\hline & $\begin{array}{l}\text { X22: Management of the hotel's online comments involves developing } \\
\text { performance indicators with standard results }\end{array}$ & 0.904 & 0.893 \\
\hline & $\begin{array}{l}\text { X23: Management of the hotel's online comments involves identifying general best } \\
\text { practices for hotels and comparing them with the hotel's practices }\end{array}$ & 0.764 & 0.794 \\
\hline & $\begin{array}{l}\text { X24: Management of the hotel's online comments involves a strategic plan for } \\
\text { continuous improvements in service }\end{array}$ & 0.719 & 0.753 \\
\hline
\end{tabular}

Note. $\mathrm{KMO}=0.945$ Barlett's sphericity test $X^{2}(120)=8590.039(p=0.000)$ Residuals $=20 \%$

Source: Authors.

\section{3 Controlling and improving outcomes}

In the third phase, as shown in table 5, two factors have been established to control and improve outcomes. The first factor consists of 4 items related to review ranking methodologies, which explains $47.21 \%$ of the variance. The second factor combines 4 items related to improve reputational scores, which explains $39.21 \%$ of the variance.

Table 5 - Dimensionality and reliability analysis: controlling and improving outcomes

\begin{tabular}{|c|c|c|c|}
\hline Factors & Variables & $\begin{array}{l}\text { Factor } \\
\text { Loadings }\end{array}$ & Communalities \\
\hline \multirow{4}{*}{$\begin{array}{l}\text { Reviewing ranking } \\
\text { methodologies } \\
47.216 \% \\
\alpha=0.982\end{array}$} & X25: Knowing the general rating scales & 0.924 & .954 \\
\hline & X26: Knowing the scales or subscales of specific ratings & 0.923 & .949 \\
\hline & X27: Knowing the suggested elements that are evaluated & 0.946 & .950 \\
\hline & X28: Knowing the factors included in the ranking positions & 0.928 & .942 \\
\hline \multirow{4}{*}{$\begin{array}{l}\text { Improving reputational } \\
\text { scores } \\
39.218 \% \\
\alpha=0.902\end{array}$} & $\begin{array}{l}\text { X29: Posting signs throughout the hotel, identifying the hotel as a } \\
\text { participant in review sites }\end{array}$ & 0.747 & .696 \\
\hline & $\begin{array}{l}\text { X30: Cards are available for customers with information from the review } \\
\text { sites where the hotel is present }\end{array}$ & 0.791 & .720 \\
\hline & $\begin{array}{l}\text { X31: Customers receive email reminders to leave comments and reviews } \\
\text { about the hotel }\end{array}$ & 0.906 & .864 \\
\hline & $\begin{array}{l}\text { X32: I.T. applications are used to manage reminders for customers to } \\
\text { leave comments about the hotel }\end{array}$ & 0.895 & .840 \\
\hline
\end{tabular}

Note. $\mathrm{KMO}=0.844$ Barlett's sphericity test $\mathrm{X}^{2}(28)=3582.741(\mathrm{p}=0.000)$ Residuals $=17 \%$

Source: Authors.

\section{Conclusion}

This research presents the findings of a field study focused on hotels' UGC-R response strategies. Prior studies have highlighted the need for further research on UGC-R strategies (e.g., Baka, 2016; Cheng et al., 2014; Kim et al., 2015; Molinillo et al., 2016; Levy et al., 2013; Park et al., 2013). Thus, certain areas have been identified that require further research, such as how to manage the identification and analysis of UGC-R, how to manage reviews and ratings, and how to control and improve results. This paper proposes a scale for measuring UGC-R 
response strategies and offers key relevant information, contributing to filling the gap in the literature by offering a quantitative tool to study the phenomenon.

Regarding UGC-R, the emergence of UGC has prompted hotels to manage their respective reputations, but there is a general lack of indications regarding applicable procedures. In order to achieve our research objectives, we confirmed the relationship between the 6 dimensions of Baka's UGC-R model (2016), in accordance with the literature: identifying the reputation landscape; assessing changes in the company's ratings and rankings over time; determining the publication reach and readership; comparing with industry competitors; reviewing and comparing ranking methodologies; and improving of reputational scores. Since each dimension seems to work for a different target, the dimensions were analyzed to see if they could be aggregated based on a common objective: identifying the reputation landscape and assessing changes in the company's ratings and rankings over time were aggregated in "methodology identification and analysis"; determining the publication reach and readership and comparing it with industry competitors were aggregated in "management reviews and ratings"; and reviewing and comparing ranking methodologies and improving reputational scores were aggregated in "improving outcomes".

The study's findings shed light on the UGC-R phenomenon. The relevance of the theoretical work and exploratory empirical analysis carried out in this research can be summarized in the following contributions: firstly, a measurement instrument was proposed for a UGC-R response strategy; secondly, three main criteria were identified in accordance with the literature and verified with the UGC-R model; thirdly, a reference theoretical framework was developed in order to focus the content and meaning of each of the identified criteria. These three exploratory factor analyses of the collected data constitute an initial approach to validating the existence of an underlying organization for each of the identified criteria. The findings confirm the existence of a practical framework that backs up the theoretical proposal.

Some limitations and areas for future research were identified during the research process. Firstly, as we only offer an exploratory analysis approximation for the three proposed main dimensions in the UGC-R model, future research should focus on analyzing these criteria changes as measurement models and their possible inclusion in a structural model, related to the criteria used, as well as assessing their impact on the tourism industry. Secondly, since our study is based on data from multiple hotels and key informants, it would be interesting to compare results from the perspectives of employees or managers or other tourism organizations participating in review sites, such us tourist destinations and restaurants. Thirdly, other review sites could be considered in future research.

Finally, considering that research into UGC-R requires more attention and the aforementioned research limitations, the following recommendations are suggested: future research should study quantitative methodologies for measuring UGC-R, how to adapt the culture of the organization to UGC-R, and how to measure objectives obtained from applicable UGC-R.

\section{References}

Arsal, I., Woosnam, K. M., Baldwin, E. D., \& Backman, S. J. (2010). Residents as travel destination information providers: An online community perspective. Journal of Travel Research, 49(4), 400-413.

Ardizzone, E., Di Miceli, F., La Cascia, M., \& Mazzola, G. (2012). Extracting touristic information from online image collections. In Signal Image Technology and Internet Based Systems (SITIS), 2012 Eighth International Conference on 25-29 Nov. 2012 (pp. 482-488). Retrieved March 6, 2016 from http://ieeexplore.ieee.org/xpls/abs_all.jsp?arnumber=6395133.

Axup, J., \& Viller, S. (2005). Augmenting travel gossip: Design for mobile communities. In Proceedings of the 17th Australia conference on Computer-Human Interaction: Citizens Online: Considerations for Today and the Future (pp. 1-4). Retrieved March 6, 2016 from http://dl.acm.org/citation.cfm?id=1108436.

Baka, V. (2016). The becoming of user-generated-reviews: looking at the past to understand the future of managing reputation in the travel sector. Tourism Management, 53, 148-162, DOI: 10.1016/j.tourman.2015.09.004.

Baka, V., \& Scott, S. V. (2009). Web 2.0 and user-generated-content in the travel industry-next step, or current reality? In International conference in tourism. 4 international scientific conference, "Planning for the future e Learning from the Past: Contemporary developments in tourism, travel \& hospitality". Rhodes Island, Greece.

Berger, I. E., \& Greenspan, I. (2008). High (on) technology: Producing tourist identities through technologized adventure. Journal of Sport \& Tourism, 13(2), 89-114.

Chan, N., \& Denizci-Guillet, B. (2011). Investigation of social media marketing: how does the hotel industry in Hong Knog perform in marketing on social media websites? Journal of Travel and Tourism Marketing, 28(4), 345-368.

Cheng, V. T. P., \& Loi, M. K. (2014). Handling negative online customer reviews: the effects of elaboration likelihood model and distributive justice. Journal of Travel \& Tourism Marketing, 31(1), 1-15.

Choi, S., Lehto, X. Y., \& Morrison, A. M. (2007). Destination image representation on the web: Content analysis of Macau travel related websites. Tourism Management, 28(1), 118-129.

Cox, C., Burgess, S., Sellitto, C., \& Buultjens, J. (2009). The role of usergenerated content in tourists' travel planning behavior. Journal of Hospitality Marketing \& Management, 18(8), 743-764.

Duffy, A. (2015). The road more travelled: how user-generated-content can lead to homogenized travel journalism. Journal of Media \& Cultural Studies, 29(6), 821-832, DOI: 10.1080/10304312.2015.1073686.

Dwivedi, M., Yadav, A., \& Patel, V. R. (2009). The online destination image of Goa. Worldwide Hospitality and Tourism Themes, 1(1), 25-39.

Filieri, R., \& McLeay, F. (2014). E-WOM and accommodation: An analysis of the factors that influence travelers' adoption of information from online reviews. Journal of Travel Research, 53(1), 44-57.

Fombrun, C. J. (2007). List of lists: a compilation of international corporate reputation ratings. Corporate Reputation Review, 10(2), 144153.

Garrido-Moreno, A. \& Lockett, N. (2016). Social Media Use in European Hotels: Benefits and Mani Challenges. Tourism \& Management Studies, 12(1), 172-179. 
Girardin, F., Calabrese, F., Fiore, F. D., Ratti, C., \& Blat, J. (2008). Digital footprinting: Uncovering tourists with user-generated content. Pervasive Computing, IEEE, 7(4), 36-43.

Girardin, F., Dal Fiore, F., Blat, J., \& Ratti, C. (2007). Understanding of tourist dynamics from explicitly disclosed location information. Retrieved March 3, 2016 from http://senseable.mit.edu/papers/pdf/2007_Girardin_et_al_Tourist_dy namics_LBS-TC.pdf.

Gretzel, U., \& Yoo, K. H. (2008). Use and impact of online travel reviews. In P. O'Connor, W. Höpken, \& U. Gretzel (Eds.), Information and communication technologies in tourism 2008 (pp. 35-46). Vienna: Springer.

Gretzel, U., Yoo, K. H., \& Purifoy, M. (2007, February). Online travel review study: Role $\&$ impact of online travel reviews. Retrieved March 3 , 2016

from http://www.tripadvisor.com/pdfs/OnlineTravelReviewReport.pdf.

Herrero, A., Marin, HS, Hernandez, JM. (2015): How online search behabior is influenced by user-generated content on review websites and hotel interactive websites. International Journal of Contemporary Hospitality Management, 27(7), 1573-1597. Doi: 10.1108/IJCHM-052014-0255.

Hoffman, D. \& Fodor, M. (2010, fall). Can you measire the ROI of Your Social Media Marketing? MITSloan Management Review, 52(1), 41-49. Retrieved March 3, 2016 from: https://www.researchgate.net/publication/228237594_Can_You_Mea sure_the_ROI_of_Your_Social_Media_Marketing.

Hvass, K. A., \& Munar, A. M. (2012). The takeoff of social media in tourism. Journal of Vacation Marketing, 18(2), 93-103.

Hwang, Y. H., Jani, D., \& Jeong, H. K. (2013). Analyzing international tourists' functional information needs: A comparative analysis of inquiries in an on-line travel forum. Journal of Business Research, 66(6), 700-705.

Jeacle, I. \& Carter, C. (2011): In TripAdvisor we trust: Rankings, calculative regimes and abstract systems. Accounting, Organizations and Society, 36, 293-309.

Jin, SV \& Phua, J. (2016). Making reservations online: The impact of consumer-written and system-aggregated user-generated content (UGC) in traver booking websites on consumers'behavioral ntentions. Journal of travel \& tourism marketing, 33(1), 101-117. Doi: 10.1080/10548408.2015.1038419.

Kim, J., Naylor, G. Sivadas, E., \& Sugumaran, V. (2015). The unrealized value of incentivized eWOM recommendations. Marketing Letters, online publication. Doi: 10.1007/s11002-015-9360-3.

Kurashima, T., Tezuka, T., \& Tanaka, K. (2005). Blog map of experiences: Extracting and geographically mapping visitor experiences from urban blogs. In A. H. H. Ngu, M. Kitsuregawa, E. J. Neuhold, J.-Y. Chung, \& Q. Z. Sheng (Eds.), Web Information Systems Engineering-WISE 2005 (pp. 496-503). Berlin, Germany: Springer Berlin Heidelberg.

Kwok, L., \& Yu, B. (2013). Spreading social media messages on Facebook: An analysis of restaurant business-to-consumer communications. Cornell Hospitality Quarterly, 54(1), 84-94.

Law, R., \& Cheung, S. (2010). The perceived destination image of Hong Kong as revealed in the travel blogs of mainland Chinese tourists. International Journal of Hospitality \& Tourism Administration, 11(4), 303-327.

Leung, D., Law, R., van Hoof, H., \& Buhalis, D. (2013). Social media in tourism and hospitality: A literature review. Journal of Travel \& Tourism Marketing, 30(1/2), 3-22.

Leung, R., Schuckert, M., \& Yeung, E. (2013). Attracting user social media engagement: A study of three budget airlines Facebook pages (pp. 195-206). Springer Berlin Heidelberg.
Levy, S., Duan, W., \& Boo, S. (2013). An Analysis of One-Star Online Reviews and Responses in the Washington, D.C., Lodging Market. Cornell Hospitality Quarterly, 54(1) 49-63.

Li, H., Ye, Q., \& Law, R. (2012). Determinants of customer satisfaction in the hotel industry: An application of online review analysis. Retrieved $\begin{array}{llll}\text { March } & 1, & 2016 & \text { from }\end{array}$ http://www.tandfonline.com/doi/abs/10.1080/10941665.2012.708351.

Liu, Y. (2012). The influence factors to the enterprise microblogs: A research of the restaurant enterprise microblogs on Weibo.com. In Computing Technology and Information Management (ICCM), 2012 8th International Conference on Apr. 24-26, 2012 (Vol. 2, pp. 590-595). $\begin{array}{llll}\text { Retrieved } \quad \text { March } & 2016 & \text { from }\end{array}$ http://ieeexplore.ieee.org/xpls/abs_all.jsp?arnumber=6268568.

Lu, X., Wang, C., Yang, J. M., Pang, Y., \& Zhang, L. (2010). Photo2Trip: Generating travel routes from geo-tagged photos for trip planning Proceedings of the international conference on multimedia (pp. 143152). Retrieved March 3, 2016 from http://dl.acm.org/citation.cfm?id=1873972.

Lu, W., \& Stepchenkova, S. (2012). Ecotourism experiences reported online: Classification of satisfaction attributes. Tourism Management, 33(3), 702-712.

Lu, W., \& Stepchenkova, S. (2015). User-generated content as a research mode in tourism and hospitality applications: Topics, methods, and software. Journal of Hospitality Marketing \& Management, 24(2), 119-154.

Magnini, V. P., Crotts, J. C., \& Zehrer, A. (2011). Understanding customer delight: An application of travel blog analysis. Journal of Travel Research, 50 (5), 535-545.

Marine-Roig, E. \& Anton, S. (2015): Tourism analytics with massive usergenerated content: A case study of Barcelona. Journal of Destination Marketing \& Management, 4(3), 162-172.

Marchiori, E. \& Cantoni, L. (2015): The role of prior experience in the perception of a tourism destination in user-generated-content. Journal of Destination Marketing \& Management, 4(3), 194-201.

Molinillo, S., Fernández-Morales, A., Ximénez-de-Sandoval, J.L. \& CocaStefaniak, A. (2016). Hotel Assessment through Social Media TripAdvisor Case Study. Tourism \& Management Studies, 12 (1), 15-24. Doi: $10.18089 /$ tms.2016.12102.

Nieto, J., Hernández-Maestro, R. \& Muñoz-Gallego, P. (2014). Marketing decisions, customer reviews, and business permormance: The use of the Toprural website by Spanish rural lodging establishments. Tourism Managment, 45(1), 115-123.

O Connor, P. (2011). An analysis of the use of Facebook by international hotel chains. Retrieved from http://scholarworks.umass.edu/refereed/ICHRIE_2011/Wednesday/9/.

O’ Mahony, M.P. \& Smyth, B. (2010): A classification-based review recommender. Knowledge-based Systems, 23, 323-329.

Organisation for Economic Co-operation and Development. (2001). Understanding the digital divide. Retrieved March 3, 2016 from http://www.oecd.org/dataoecd/38/57/1888451.pdf.

Pan, B., MacLaurin, T., \& Crotts, J. C. (2007). Travel blogs and the implications for destination marketing. Journal of Travel Research, 46(1), 35-45.

Paris, C. M., \& Rubin, S. (2013). Backpacking, social media, and crises: A discussion of online social convergence. In Information and Communication Technologies in Tourism 2013 (pp. 207-217). Retrieved February 5, 2016 from http://link.springer.com/chapter/10.1007/9783-642-36309-2_18.

Park, S. \& Allen, J. (2013). Responding to Online Reviews: Problem Solving and Engagement in Hotels. Cornell Hospitality Quarterly, 54(1) 64-73. 
Schmallegger, D., \& Carson, D. (2009). Destination image projection on consumergenerated content websites: A case study of the flinders ranges. Information Technology \& Tourism, 11(2), 111-127. Doi:10.3727/109830509789994838.

Sparks, B. A., Perkins, H. E., \& Buckley, R. (2013). Online travel reviews as persuasive communication: the effects of content type, source, and certification logos on consumer behavior. Tourism Management, 39(0), $1-9$.

TripAdvisor. 2016. $\quad$ Fact sheet. http://www.tripadvisor.com/PressCenter-c4-Fact_Sheet.html (accessed Abril 15, 2016).

Weilin L., \& Svetlana S. (2015) User-Generated Content as a Research Mode in Tourism and Hospitality Applications: Topics, Methods, and Software. Journal of Hospitality Marketing \& Management, 24(2), 119154, DOI:10.1080/19368623.2014.907758.

Wenger, A. (2008). Analysis of travel bloggers' characteristics and their communication about Austria as a tourism destination. Journal of Vacation Marketing, 14(2), 169-176.

\section{Appendix 1}

\section{Questionnaire}

\begin{tabular}{|c|c|c|}
\hline Variables & Questions & Answers \\
\hline \multicolumn{3}{|c|}{ I believe that the hotel's User Generated Content Review response focuses on: } \\
\hline $\begin{array}{l}\text { Identification of the reputation } \\
\text { landscape }\end{array}$ & $\begin{array}{l}\text { X1: Knowing the specific areas where customers can send or read general } \\
\text { reviews } \\
\text { X2: Knowing the specific areas where customers can send or read specific } \\
\text { reviews } \\
\text { X3: Knowing the specific areas where customers can rate general aspects of } \\
\text { the hotel } \\
\text { X4: Knowing the specific areas where customers can rate specific aspects of } \\
\text { the hotel }\end{array}$ & $\begin{array}{l}\text { 10-item Likert scale } \\
\text { (1 = strongly } \\
\text { disagree; } 10= \\
\text { strongly agree). }\end{array}$ \\
\hline $\begin{array}{l}\text { Assessment of changes in the } \\
\text { company's ratings and rankings over } \\
\text { time }\end{array}$ & $\begin{array}{l}\text { X5: Evaluating changes in the number of comments } \\
\text { X6: Evaluating changes in comments (from positive to negative and from } \\
\text { negative to positive) } \\
\text { X7: Evaluating changes in the number of ratings } \\
\text { X8: Evaluating changes in ratings (from positive to negative and from } \\
\text { negative to positive) }\end{array}$ & $\begin{array}{l}\text { 10-item Likert scale } \\
\text { (1 = strongly } \\
\text { disagree; } 10= \\
\text { strongly agree). }\end{array}$ \\
\hline Determination of publication reach & $\begin{array}{l}\text { X9: Responding promptly to positive evaluations } \\
\text { X10: Expressing thanks for evaluations made } \\
\text { X11: Giving innovative responses to comments } \\
\text { X12: Highlighting positive aspects reflected in the evaluation } \\
\text { X13: Addressing specific comments } \\
\text { X14: Expressing thanks for evaluations made about the hotel } \\
\text { X15: Apologizing for any aspects that have caused low ratings } \\
\text { X16: Explaining the aspects that have caused low ratings } \\
\text { X17: Offering the opportunity to contact the hotel in order to carefully } \\
\text { address the issue that has caused a poor evaluation } \\
\text { X18: Sharing information about corrective actions carried out based on poor } \\
\text { evaluations } \\
\text { X19: Providing some form of compensation (monetary or non-monetary) for } \\
\text { inconveniences the customer has experienced } \\
\text { X20: Inviting customers back to the hotel }\end{array}$ & $\begin{array}{l}\text { 10-item Likert scale } \\
\text { (1 = strongly } \\
\text { disagree; } 10= \\
\text { strongly agree). }\end{array}$ \\
\hline $\begin{array}{l}\text { Comparison with industry } \\
\text { competitors }\end{array}$ & $\begin{array}{l}\text { X21: Management of the hotel's online comments involves identifying and } \\
\text { prioritizing customer service attributes that influence the customer's } \\
\text { perception of the quality of service } \\
\text { X22: Management of the hotel's online comments involves developing } \\
\text { performance indicators with standard results } \\
\text { X23: Management of the hotel's online comments involves identifying } \\
\text { general best practices for hotels and comparing them with the hotel's } \\
\text { practices } \\
\text { X24: Management of the hotel's online comments involves a strategic plan } \\
\text { for continuous improvements in service }\end{array}$ & $\begin{array}{l}\text { 10-item Likert scale } \\
\text { (1 = strongly } \\
\text { disagree; } 10= \\
\text { strongly agree). }\end{array}$ \\
\hline
\end{tabular}

Xiang, Z., \& Gretzel, U. (2010). Role of social media in online travel information search. Tourism Management, 31(2), 179-188.

Ye, Q., Gu, B., Chen, W., \& Law, R. (2008). Measuring the value of managerial responses to online reviews: A natural experiment of two online travel agencies. In ICIS 2008 Proceedings (Paper 115). Retrieved April 13, 2016 from http://aisel.aisnet.org/icis2008/115.

Ye, Q., Law, R, Gu, B. \& Chen, W. (2011). The influence of usergenerated content on traveler behavior: An empirical investigation on the effects of e-word-of-mouth to hotel online bookings. Computers in Human Behavior, 27(2), 634-639.

Zhang Y. \& Vásquez (2014). Hotels'responses to online reviews: managing consumer dissatisfaction. Discourse, Context and Media, 6, 54-64.

Received: 16 February 2017

Revisions required: 25 July 2017
Accepted: 10 September 2017 
Reviewing and comparing ranking methodologies

Improving reputational scores
$X 25$ : Knowing the general rating scales

$\mathrm{X} 26$ : Knowing the scales or subscales of specific ratings in which they are present

$\mathrm{X} 27$ : Knowing the suggested elements that are evaluated on the sites where they are present

$\mathrm{X} 28$ : Knowing the factors included in the ranking positions on the sites where they are present

X29: Posting signs throughout the hotel/establishment, identifying the hotel/establishment as a participant in review sites

X30: Cards are available for customers with information from the review sites where the hotel/establishment is present

X31: Customers receive email reminders to leave comments and reviews about the hotel/establishment

X32: I.T. applications are used to manage reminders for customers to leave comments about the hotel/establishment 10-item Likert scale

(1 = strongly

disagree; $10=$

strongly agree).

10-item Likert scale

(1 = strongly

disagree; 10 =

strongly agree)

Source: Authors. 